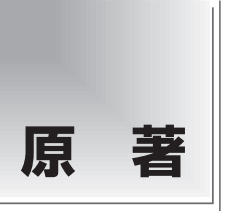

論文受付

2018 年 11 月 15 日

論文受理

2019 年 2 月 5 日

Code Nos. 251

532

\section{一般撮影検査における自動ポジショニング法開発の試み}

一頸椎 4 方向撮影への応用—

\author{
鶴岡礼奈 ${ }^{1}$ 白石順二 ${ }^{2}$ \\ 1 熊本大学大学院保健学教育部 \\ 2 熊本大学大学院生命科学研究部
}

\section{緒 言}

近年, コンピュー夕断層診断 (computed tomography: CT) や核磁気共鳴画像 (magnetic resonance imaging: MRI) といった画像診断領域における診断技術が 著しく進展し，これまでは画像化が困難であった病変 が描出可能となってきている。しかし，CT や MRI は 検查コストが高額となるため, さまざまな部位の疾患 の検索や経過観察においては, 依然として単純 X 線 撮影が幅広く用いられ，その重要性は今日でも変わる ことはない.

一般撮影検査に扔いては, 本来, 撮影を行う診療放 射線技師 (以下, 技師)が違っていても, 同じ撮影法に
関しては，ポジショニングや撮影線量といった点で画 像の質が変化しないことが望ましい，特に経過観察の 患者では, 過去画像と現在画像でポジショニングの違 いによって対象部位に大きな変化があった場合, 正し い診断が困難になってしまう。しかし，実際の現場で は，技師の経験や技量の差によって，ポジショニング 角度や撮影線量が異なることで, 同一患者の同一部位 であっても画像間に差が生じる場合があり，また，撮 影部位によっては, 診断に有効でないという理由から 再撮影となる場合もある1).

一方，最近では，一般社会だけでなく，医療分野で もコンピュータ技術を用いた自動化に関する研究開発

\title{
Development of Automated Positioning System in General Radiography Examination -Application to Four Directions Cervical Spine Radiography-
}

\author{
Reina Tsuruoka ${ }^{1 *}$ and Junji Shiraishi ${ }^{2}$ \\ ${ }^{1}$ Graduate School of Health Sciences, Kumamoto University \\ ${ }^{2}$ Faculty of Life Sciences, Kumamoto University
}

Received November 15, 2018; Revision accepted February 5, 2019

Code Nos. 251, 532

\section{Summary}

To reduce a number of retaking with unnecessary radiation exposure, and to improve a quality of general radiography and efficiency of radiographic procedure, we propose an automated radiographic system that uses reference points on human face for determining exposure angle and beam center. As a preliminary study, we developed an automated positioning method for determining exposure angle and beam center of four directions (4R) cervical spine radiography by using the human body data from 3D reconstructed head-and-neck computed tomography (CT) images. An image for recognizing human-face was reconstructed and used for identifying the reference points. Clinical utility of this proposed method was demonstrated by using "KENZO" to inspect simulated projection X-ray images which were reconstructed from CT volume data. In this study, we reused a huge number of CT images, which were obtained in routine clinical procedure and had archived in medical institutions. This database, therefore, allowed us to develop a new radiological technique without any additional patient dose.

Key words: general radiography, four directions cervical spine radiography, automated general radiography, automated positioning system, computed tomography (CT)

*Proceeding author 
や実用化が進んでいる，例えば，放射線治療分野にお ける代表例として，サイバーナイフを用いた定位放射 線治療が挙げられる。 サイバーナイフとは, 高精度口 ボットアームに高エネルギー放射線照射装置(リニ アック)を組み合わせた装置で, 定位放射線治療で必 要とされる多方向からの照射をロボットアームにより 可能としている，照射中はロボットアームとは別に， 天井に設置された 2 台の $\mathrm{X}$ 線撮影装置で常に標的を 監視し，標的の動きに合わせて目標位置が自動修正さ れ，常に標的に対して正確な照射が行われる。このよ うにサイバーナイフは, ほかの多くのリニアック装置 と異なり, 定位放射線治療に特化した装置であり, 高 精度の治療が比較的容易に実現できるため，導入する 施設が近年増加している ${ }^{2,3)}$.

一般撮影においては，X線管と検出器の位置を同期 させることで, 照射野を検出器に一致させて撮影を行 う装置が以前より市販化され，一般的に使用されてい る。それに加えて, 定位放射線治療装置であるサイ バーナイフで用いられているような, 患者ポジショニ ングに打ける撮影台やX 線管装置の移動や角度づけ をコンピュータ制御により自動で行うといった機能, 更に, カメラなどによる顔認識機能を一般撮影装置に 装備させることが可能になれば, 撮影担当技師の違い による撮影画像の差がなくなり，撮影の効率化や再撮 影減少による患者被ばくの低減, 再現性の向上が期待 される。

本研究では, 一般撮影技術への顔認識技術の応用に 際して, カメラ画像ではなく CT 画像から被検者の顔 表面の凹凸情報を二次元画像化することにより得られ た外観情報を用い，自動的にポジショニングを行う手 法の開発を目的とする.

一般的に，撮影法開発においては，開発された撮影 技術の正確さを検証する必要があるが, 被検者に対す る侵襲的行為(被ばく)は認められていないため, 検証 の手段が限定されてしまう。そこで，本研究では，通 常の検査目的で施行され, その後, 医療機関に保管さ れている大量の CT 検查画像から, 一般撮影における 撮影技術開発のために必要な三次元画像デー夕を再構 成することで，仮想人体データベースを作成した，そ れらの仮想人体に対してシミュレーションによりX 線を照射し, 模擬的にX 線投影像を得ることで, 自動 ポジショニング法の検証を可能にした.

本研究では, 自動ポジショニング法開発の初期検討 として, 頸椎 4 方向 (正面, 側面, 右斜位, 左斜位)撮影 について検討を行った。

\section{1. 方 法}

\section{1-1 自動ポジショニング法の考え方}

本研究に抢ける自動ポジショニング法とは, 被検者 の外観情報から, 入射するX 線の被検者の体内にお ける線束中心(ビームセンタ)の三次元座標を決定した うえで, そのビームセンタに対するX X 線の入射角度 および照射野の大きさを撮影法ごとに自動的に決定す る手法を意味する。つまり, 従来の一般撮影の手法の ように, 被検者の外観から入射点を決定するのではな く, 放射線治療の位置決めで用いられるような, 体内 のビームセンタの三次元座標を外観情報から推測する ことで, ポジショニングを行うという新しい考え方を 用いる。

本研究の頸椎 4 方向の自動ポジショニング法では, 頭頸部 CT 画像を再構築して得られた頭頸部三次元画 像の外観情報から, 頸椎 4 方向撮影のポジショニング に必要であろうと考えられる基準点(鼻尖, 左右外耳 孔）を自動検出し，ビームセン夕および入射角を決定 する手法を開発した。また，決定したビームセンタと 入射角を用いて, 頸椎 4 方向撮影の X 線透過像を CT 画像からシミュレーションにより再構成し, 再構成画 像を検像することで, 本手法の有用性を検証した。 三 次元 CT 画像データからビームセンタを決定するまで のアウトラインを Fig. 1 に, 詳細について以下に示す.

\section{1-2 画像データベース}

本研究では, 本学附属病院において, 通常の診療目 的で撮影された頭頸部 CT 画像 80 例を使用した。撮 影には, $40 \mathrm{~mm}$ のボリュームディテクタを搭載した 64 列マルチスライス CT 装置, Brilliance CT 64(フィ リップスメディカルシステムズ)を使用した。オリジ ナルデータのマトリクスサイズは $512 \times 512, \mathrm{FOV}$ (field of view) $250 \mathrm{~mm}$, スライス厚 $3 \mathrm{~mm}$, 再構成サ ンプリングピッチ $3 \mathrm{~mm}$, スライス枚数 68-117 枚, $\mathrm{XY}$ 平面 (Axial 平面)に拈けるピクセルサイズ 0.488 mm, グレイスケール 16 bitで, ヘッダ情報をすべて削 除し, RAW 画像データフォーマットで保存したもの を本研究の画像データベースとした，な拉，本研究の 使用画像については, 当該倫理審査委員会の承認を受 け，患者の個人情報を保護するために，画像デー夕を 病院外へ持ち出す前に, 院内 ID を研究用 ID で匿名 化し，氏名等の個人情報を削除して，管理・保管した。 本研究に扔いては, 全 80 例のうち, ランダムに抽出 した 30 例を自動ポジショニング法におけるさまざま なパラメータの決定に使用し, 残りの 50 例を開発し た手法の検証に用いた。 


\section{1-3 三次元画像データの作成}

オリジナルの CT 画像データのボクセルサイズは $0.488 \times 0.488 \times 3 \mathrm{~mm}$ の非等方性であり, この画像から 三次元画像データを作成すると, $Z$ 軸方向に対して空 間情報が不足したものとなる。そのため，スライス間 の画像を線形補間によって追加作成することで， $\mathrm{x}$, $\mathrm{y}, \mathrm{z}$ 軸のそれぞれの方向について同じサイズである 等方性のボクセルをもつ三次元画像データを作成した.

また，本研究では被検者の皮膚表面のみを外観情報 として利用するため, 再構成した三次元画像データか ら検査着やチューブ等を除いた皮膚表面のみの表示に 合わせて，CT 值-200 を闇值とした閾值処理を行い, 被検者の外観情報とした。処理後の被検者の外観情報 の一例を, 三次元画像データのボリュームレンダリン グ表示により Fig. 2 に示す.

\section{1-4 顔認識画像の作成}

本研究では，被検者の顔の位置と傾きを自動認識す るための基準点として, 体型や性別に関係なく検出可 能である以下の 3 点を選択した；1) 鼻尖 (被検者の正 中を示す), 2)左右の外耳孔 (2 点を結んだ線の中点を 求めることで，被検者の頭が傾いている場合も正しい 結果が得られる).そして，これらの基準点の三次元 的配置から，頸椎 4 方向撮影の際に入射中心となる ビームセンタを決定することが可能になると仮定した。

CT 画像より得られた被検者の外観情報を用いて, 前述の基準点(鼻尖，左右外耳孔）を検出するために， 最初に, 正面と左側面の 2 方向について顔認識画像を 作成した。作成した顔認識画像の一例を Fig. 3 に示 す。顔認識画像は， $512 \times 512$ の二次元画像における被 検者の顔表面から $\mathrm{y}=0$ (正面像)，または $\mathrm{x}=0$ (側面像) までの直線距離を画素值に置き換えて画像化したもの で，顔の凹凸に応じて，正面像における鼻尖のように 凸の部分は白く，側面像における耳孔のように凹の部 分は黒く表示される.

\section{1-5 基準点の自動検出}

基準点の自動検出方法について, 以下に示す。な お，基準点の自動検出におけるすべてのパラメータ は, 自動ポジショニング法開発用にランダム抽出した 30 例を用いて，経験的に決定した。

\section{1-5-1 鼻尖}

鼻尖の検出は, 顔認識画像の正面像を用いて行っ た。画像中の被検者の頭部上部 $(\mathrm{y}=10)$ と頭部下部 $(\mathrm{y}$ : 等方ボクセル化後のスライス枚数/3)の各々の中点を 結んだセンターライン上に， $\mathrm{x}$ 軸方向への横幅が 40

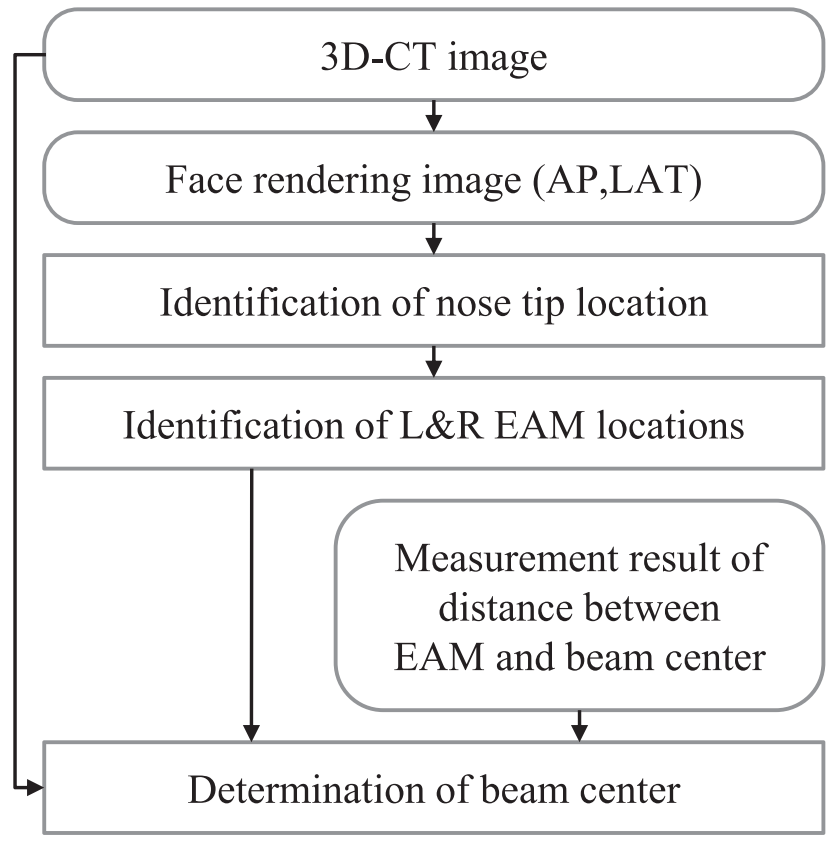

Fig. 1 The outline of computerized scheme for determining the beam center from 3D-CT image.

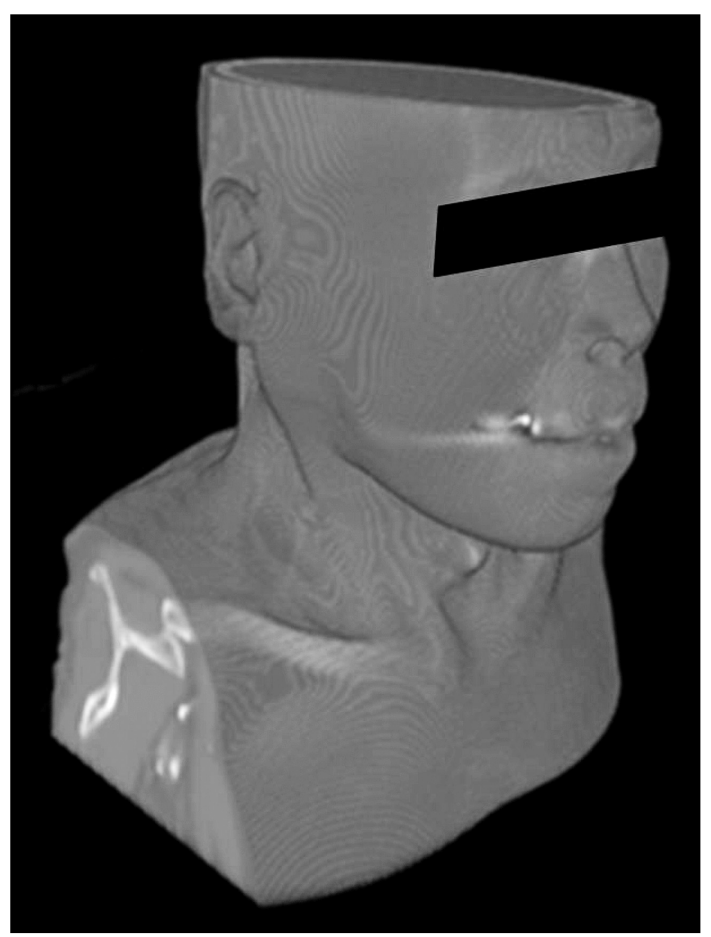

Fig. 2 Example of isotropic 3D-CT image with surface thresholding.

ピクセルであるようにサーチエリアを設定した(Fig. 4a)。そのサーチエリア内で顔認識画像における画素 值が最も高い点を鼻尖であると決定した(Fig. 4b).

\section{1-5-2 外耳孔}

外耳孔の検出は, 顔認識画像の左右側面像において 行った。耳介があると予測される範囲を耳介部領域画 

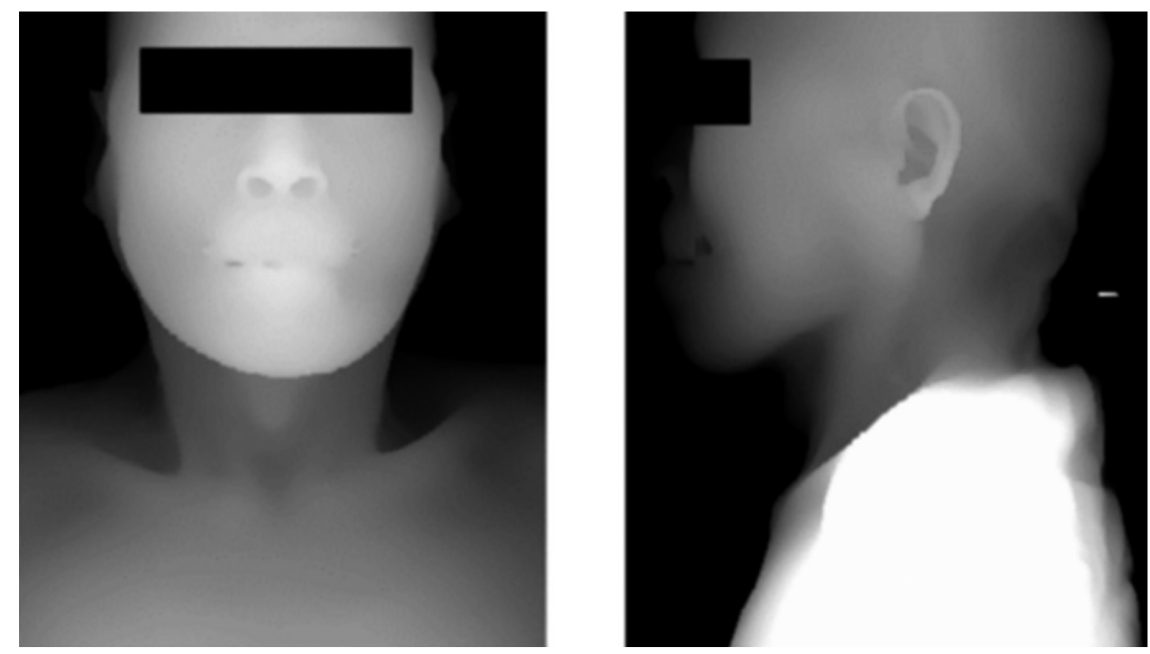

$a \mid b$

Fig. 3 Examples of face rendering images reconstructed from 3D-CT images.

(a) Front view, (b) Left lateral view
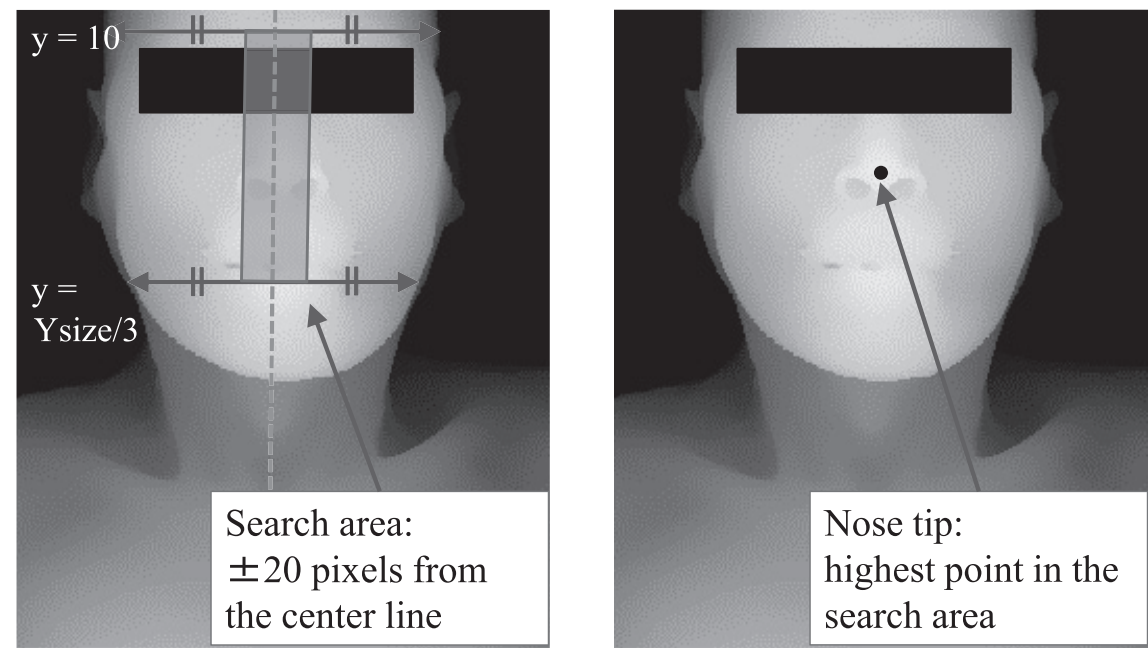

a $\quad b$

Fig. 4 Identification of nose tip from front view of face rendering image.

(a) Setting of search area for the identification of nose tip

(b) Determination of a nose tip location at the highest pixel value point on the search area

像として切り出すため, 切り出しの範囲を $128 \times 128$ pixel と設定し，1-5-1 で求めた鼻尖の位置情報から耳 介部領域画像を作成する位置を決定した(Fig. 5a). 本手法では，側面顔認識画像における鼻尖と外耳孔の 高さはほぼ同じであると仮定し, 耳介部領域画像の中 心点と鼻尖の高さは同じであるとした。また，耳介は 頭部全体の少し後方寄りにあると仮定し，鼻尖と頭部 後方を結んだ直線上の $3 / 5$ だけ鼻尖から離れた点を， 側面顔認識画像の $\mathrm{x}$ 方向についての耳介部領域中心 点と決定した。

作成した耳介部領域画像に対して，差分フィルタ ${ }^{4)}$ を適用することで画像内の凹の部分を反転強調した画 像を作成 (Fig. 5b), その後, 多重閾值処理とルール識 別器を用い ${ }^{4)}$, 外耳孔の位置を決定した (Fig. 5c).
ルール識別器とは, 多重閾值処理を終了させる閾值を あらかじめルールとして設定しておくものであり, 本 研究では，多重閾值処理によって二值化した場合に， 外耳孔が存在する可能性が高い範囲(切り出した範囲 の中央 $1 / 4$ の面積の範囲)における二值化画像内の候 補領域の円型率が 0.7 以上から 0.7 未満に急に下がる 值の直前の值を実際の閾值とし (Fig. 6), その候補領 域を外耳孔とて，その重心を外耳孔中心としだ）。

\section{1-6 ビームセンタの決定}

本手法では，検出した鼻尖と左右の外耳孔中心の座 標の三次元的配置から, 頸椎 4 方向撮影の際のビーム センタの三次元座標を決定した. 一般的に, 頸椎 4 方 向撮影の場合のビームセンタは, 正面, 左側面, 右斜 


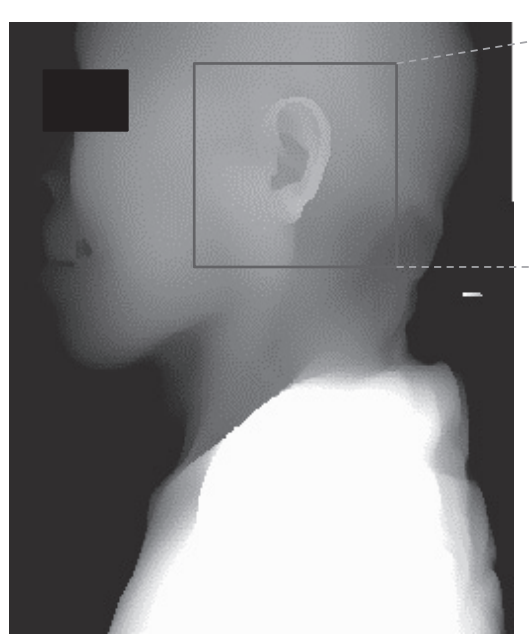

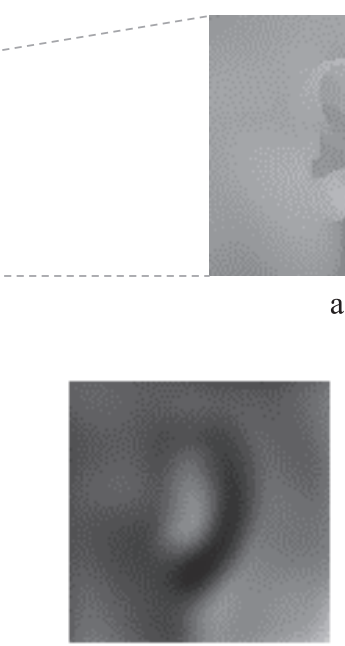

b

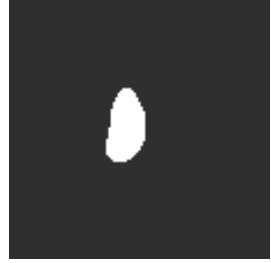

c

Fig. 5 Identification of an external acoustic meatus (EAM) from the lateral view of the face rendering image.

(a) Auricle region image extracted from the face rendering image by using a nose tip location

(b) Application of a difference filter to enhance EAM in auricle region image

(c) Determination of EAM location by using multiple threshold technique and a rulebased classifier on the difference filter image

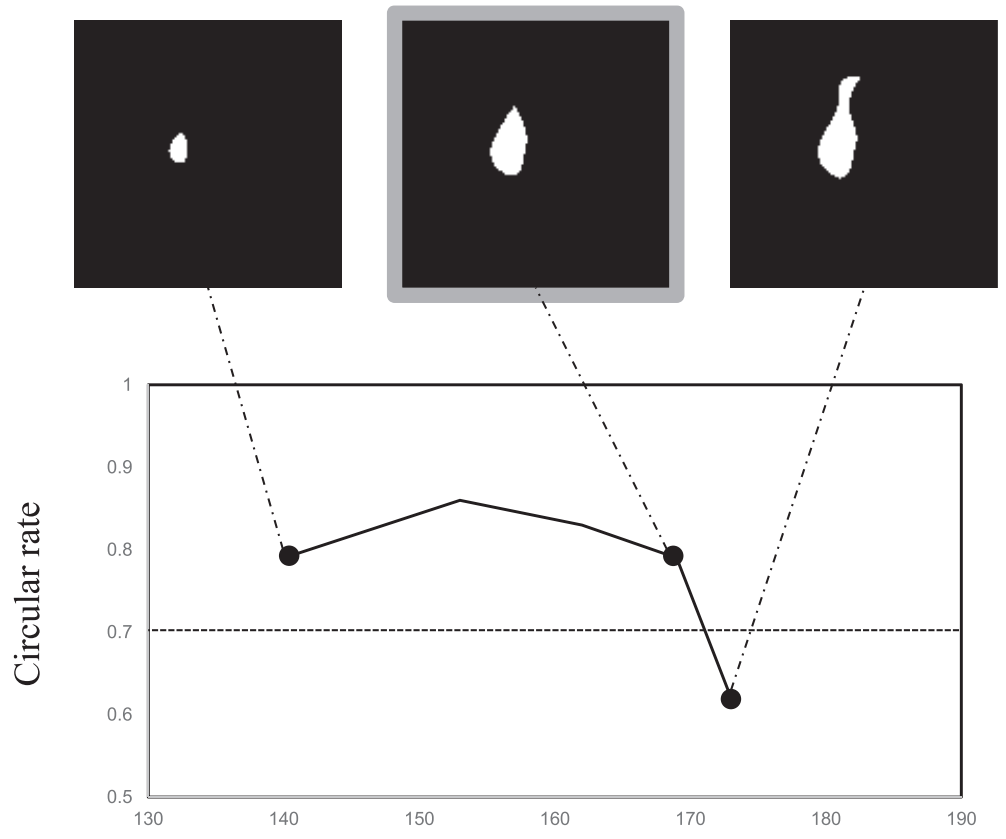

Threshold pixel value

Fig. 6 Application of a multiple threshold technique and a rule-based classifier.

位，左斜位，各々の入射中心の線の交点で求められる ため，一般的な撮影法の文献に示されている頸椎 4 方 向撮影の際の入射角度に準じて, 本手法では CT 画像 横断面における第 4 頸椎椎体の後方をビームセンタと 決定した(Fig. 7).

また，外観からはビームセンタである第 4 頸椎椎体
後方の点を目視することができないため，1-5-2で検 出した外耳孔中心との位置関係から，その位置を推測 した. 左右外耳孔の中点とビームセンタとの距離を,

A-P (Anterior-Posterior) 方向についてX, S-I (Superior-Inferior)方向についてYとした(Fig. 7 左). そして, 画像データベース 80 例のうち 30 例の CT 画 


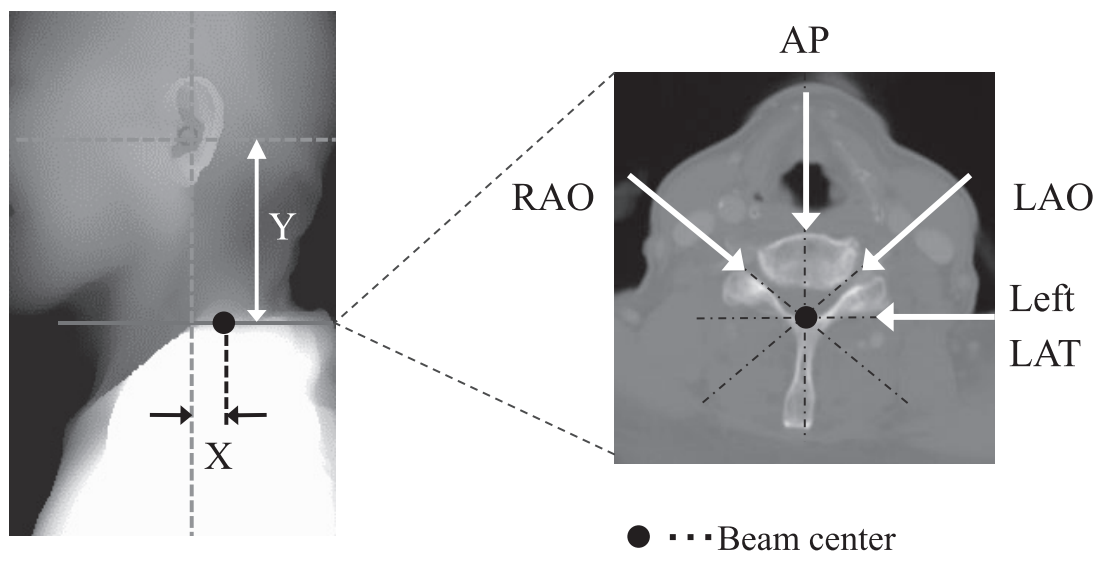

Fig. 7 A beam center location of $4 \mathrm{R}$ cervical spine radiography (right) at the level of fourth cervical spine.

Distances $(\mathrm{X}, \mathrm{Y})$ in A-P and S-I direction between the midpoint of left and right EAM and the beam center, respectively, were measured for 30 cases.
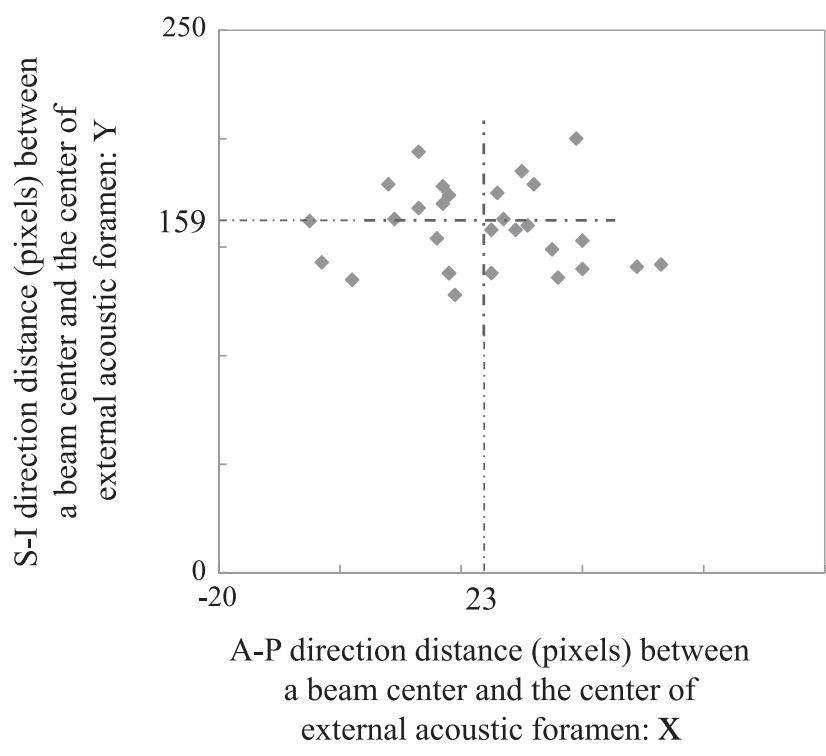

Fig. 8 Distribution of two measured distances obtained from 30 cases.

像データについて，これらのXとYを測定した結果, その平均值は, $\mathrm{X}=23$ pixel $(11.2 \mathrm{~mm}), \mathrm{Y}=159$ pixel (77.6 mm) となった Fig. 8)。そこで, 本手法では, こ の值を用いることで, 外耳孔位置からビームセンタ位 置を決定した。

\section{1-7 模擬 X 線投影像の作成}

\section{1-7-1 RaySum 処理}

RaySum 処理は，CTによって再構成された横断画 像を HU(Hounsfield units) スケールのまま単純に1方 向へ加算または平均処理を行った処理で, この画像の 画素值はその画素位置における投影経路上の線減弱係 数の和に比例する ${ }^{5}$.

単純 $\mathrm{X}$ 線撮影では X 線管から X 線が放射投影され
ることから，本手法では，加算平均処理を行う方向を ビームセンタからの距離に応じて放射状に変化させた.

\section{1-7-2 模擬 X線投影像の作成}

ビームセンタの決定に用いた 30 例を除いた残り 50 例の CT 画像デー夕を用いて, 加算平均処理による模 擬 X 線投影像を作成した。作成した模擬 $\mathrm{X}$ 線投影像 は 8 bit グレイスケールで, 通常の X 線投影像と画像 の見え方が同等となるように階調反転処理を行い，透 過 X 線量が多いほど画素值が 0 に近づき，黒くなる 階調とした。

頸椎 4 万向撮影におけるX 線の入射角や焦点一検出 器間距離 (source image receptor distance: SID) は, 一 般的に文献6.7)に記載されているデー夕を参照して, 正面像と斜位像については尾頭方向に $15^{\circ}$, SID は 150 $\mathrm{cm}$ として, 加算平均処理を行った。また，側面像に ついては左側面で, 検出器面に対して垂直にX 線が 入射するものとした。 そして, 検出器のサイズは, 一 般的に頸椎撮影で使用されている四切サイズ $(25 \times 30$ $\mathrm{cm})$ とし, 通常の撮影で得られるX 線像を再現するた め, X 線の照射範囲をコリメータで横幅 $18.75 \mathrm{~cm}$ (7.5 インチ)に設定したように見える画像処理を行った (Fig. 9).この画像処理では, 仮想照射野内に対して は $5 \times 5$ のカーネルによるアンシャープマスク処理を 行い, 仮想照射野外に対しては, 同じカーネルサイズ で平滑化処理を行ったうえで，画素值を加算して平均 処理による計算值の 4 倍にして, 照射野外の X 線像 を再現した。

\section{1-8 検像による評価}

自動ポジショニング法の正確さは, 50 例の CT 画像 データを用いて作成した模擬 X 線投影像について, 

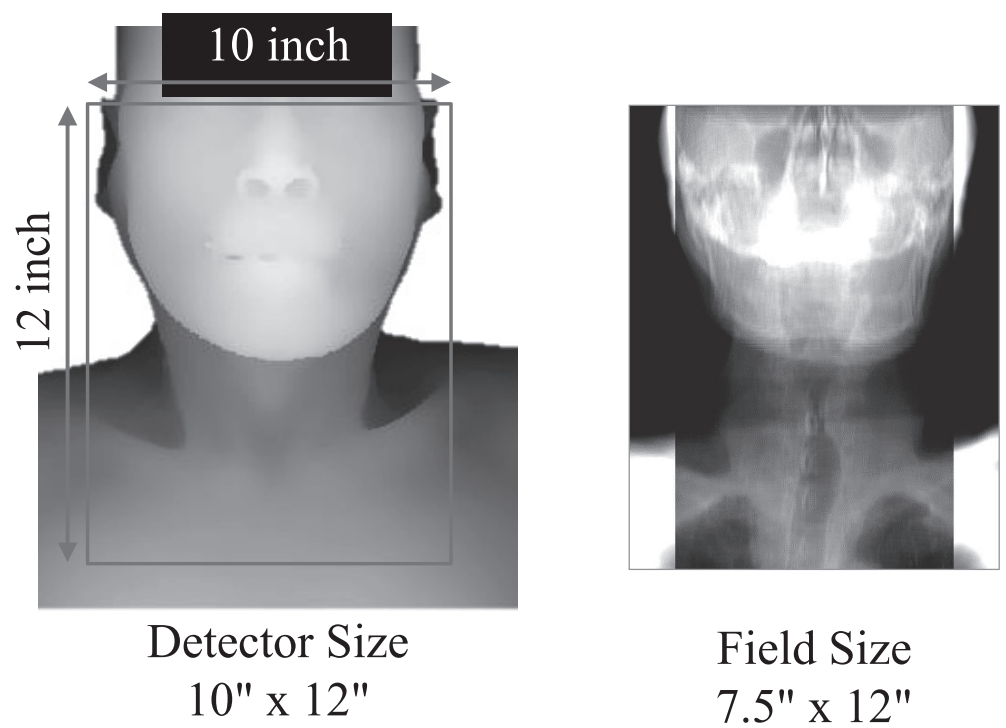

\section{Field Size}

$7.5^{\prime \prime} \times 12^{\prime \prime}$

Fig. 9 Simulated detector size and irradiation field for $4 \mathrm{R}$ cervical spine radiography.

技師 1 名(一般撮影における検像の経験 20 年)が検像 を行うことで検証した。

本研究では, 頸椎 4 方向が正しく撮像されているか どうかの検像基準として, 斜位と側面については, 第 1 頸椎から第 7 頸椎がすべて正しく含まれているこ と, そして, 斜位については椎間孔が明瞭に観察可能 であることとした，なお，正面像については，通常の 検像では下顎先端と後頭蓋窩が重なるポジショニング が正しく行われているかどうかが判断されるが，本手 法では CT 検査時に下顎を前方に出していることが稀 なため, 下顎先端と後頭蓋窩の一致については検像の 対象外として, 画像の正中線上に棘突起が位置してい るか，第 3 頸椎から第 1 胸椎までが描出されている か, という点について検像を行った。

\section{2. 結 果}

検証用の 50 例に本手法を適応した結果，基準点の 検出については, 鼻尖を誤検出したものが 1 例, 左外 耳孔を誤検出したものが1例であり, 残り 48 例にお いては, 鼻尖, 左右外耳孔ともに正しく検出された.

基準点では, 誤検出が 2 例認められたが，その 2 例 を含めたすべての 50 症例について, ビームセンタの 三次元座標を用いて再構成した模擬 X 線投影像は, いずれの症例も検像では問題がないと判定された。

基準点を正しく検出した 2 例と誤検出した 2 例の, 基準点の検出結果画像と模擬 X 線投影像を Fig. 10 に 示す.

\section{3. 考察}

Figure 10A の Case 1 の被検者は頭頸部に損傷や炎 症などの症状がなく, 顔認識に影響を与える因子が少 なかったため, 理想に近い頸椎撮影像が得られた。

Case 2 は右下顎が久損している例であるが, 基準点検 出での影響はなく, 模擬 X 線投影像も正しく作成さ れた．Figure 10B の Case 3 においては，被検者の口 唇に炎症による腫脹がみられる状態で, CT 画像上で は鼻尖よりも上口唇が高い座標を示したことが誤検出 の原因であった. Case 4 の誤検出は, 被検者の頭の傾 きと, 耳介部のつくりの個人差に対応しきれなかった ことから生じたものであると考えられる。 今後, 鼻 尖, 外耳孔検出の両方において, 手順の再検討が必要 である。

被検者の体表面に入射点を定める従来の考え方では なく, ビームセン夕の三次元座標を体表面の基準点か ら決定し，そのビームセンタに向けてX線を照射す るという，ポジショニングにおける新しい考え方は， 放射線治療の領域で長期にわたって利用されてきた考 え方を利用したものである。技師が目で見て被検者の ポジショニングを行う場合には，体表面における入射 点の位置が被検者の体格によって変化するため, 経験 則により，その入射点の位置を調整する必要がある が, ビームセンタの三次元座標に対してX線照射を 行う新しい考え方であれば，体格に影響を受けずに， 検査対象が高い割合で画像の中央となるようなポジ ショニングが可能になると考えられる，実際，本手法 を用いて得られた頸椎 4 方向の画像では, $50 \times 4$ 方向 の全 200 画像の 174 画像 $(87 \%)$ において, 頸椎椎体が 
Case 1
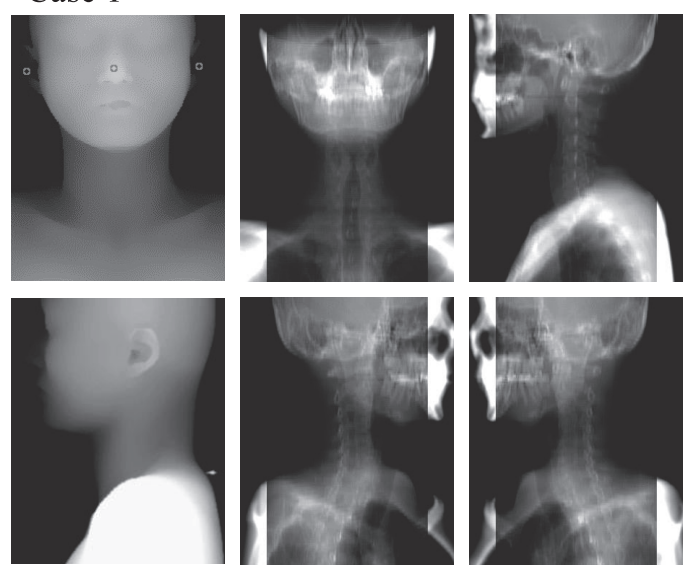

Case 3
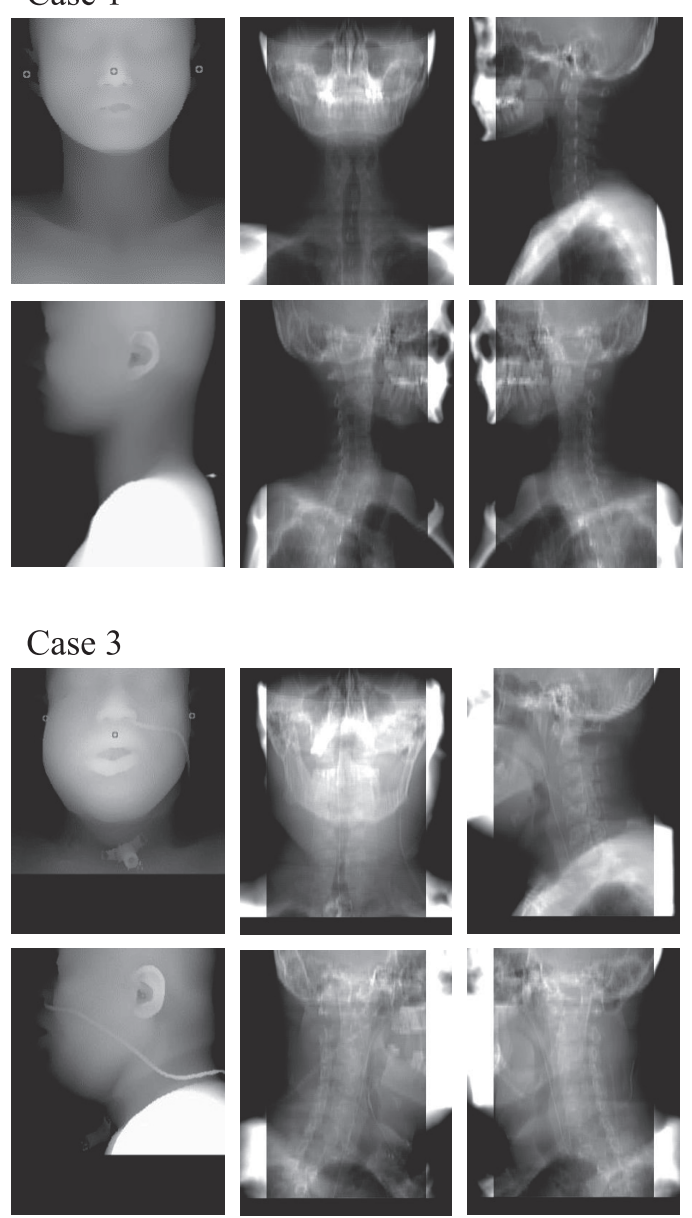

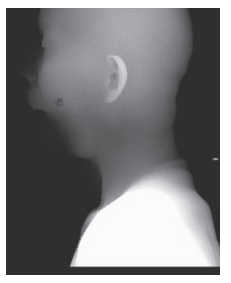

Case 2
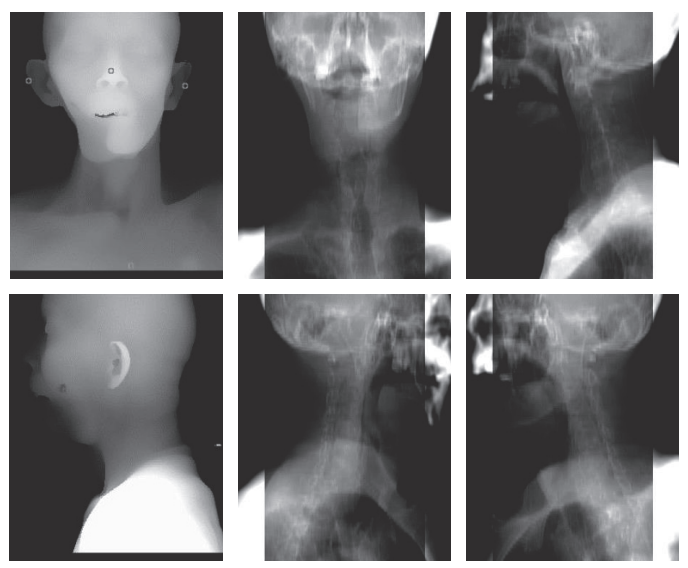

(A)

\section{Case 4}
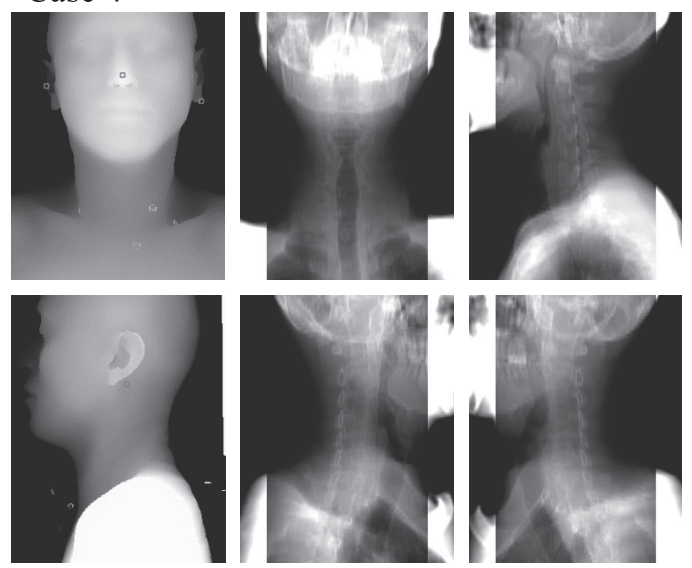

(B)
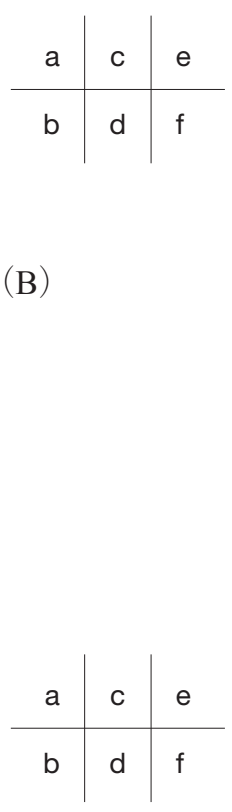

Fig. 10 (A) Examples of the correctly inspected cases of which reference points were identified suitably on the face rendering images $(a, b)$, and produced appropriate projection images for $4 \mathrm{R}$ cervical spine radiography (c-f).

(a) Front, (b) Lateral, (c) AP, (d) RAO, (e) LAT, (f) LAO

(B) Examples of the incorrectly inspected cases of which reference points were not identified on the face rendering images $(\mathrm{a}, \mathrm{b})$, but produced appropriate projection images for $4 \mathrm{R}$ cervical spine radiography (c-f).

画像の正中線と一致しており，一致が認められなかっ たのは, CT 撮影の際の枕の高さや頸椎彎曲により, 通常より頸椎が斜めに配置されている被検者, また, 頸椎変性疾患により前彎が失われている被検者であっ た。ただし，結果に示したように，一致が認められな かった症例でも，検像では，すべての症例において問 題は認められなかった。

本研究では, 院内に保存されている診療用に撮影さ れたCT画像データを用いて，一般撮影における自動 ポジショニング法の開発を行った。CT 画像の分解能 が一般撮影における画質に比べて劣るため, 細かな部 分の描出の再現については問題があるが, 本研究のよ うに，診断目的ではなく，ポジショニングの適否を確 認することが目的であれば，現状の解像度でも問題は ないと考える。しかし, 今後, CT 画像に対する機械 学習を用いた超高解像度処理などを行うことによっ
て, より実際の $\mathrm{X}$ 線投影像に近い模擬 $\mathrm{X}$ 線投影像が 作成されれば，診断を目的とした利用も可能になると 考えられる。

本研究では, 被検者の顔情報と X 線投影像を対応 させるために, 被検者の顔認識は CT の三次元画像 データから作成した画像を用いて行ったが, 本手法が 臨床で実用化される場合には，一般的に普及している カメラからの入力から鼻尖や耳孔を検出する手法の方 が精度が高いため, より正確なポジショニングが可能 になると期待される。また，本研究で用いた画像デー 夕においては, CT 検査でのポジショニング時の被検 者の頭の傾きが誤検出や画像中央からのずれの一因と なっていたため, 頭の傾きや回転の補正といった検査 時の被検者の整位を正しく行うための工夫も, 自動ポ ジショニング実現に必要であると考えられる. 


\section{4. 結 語}

自動ポジショニング法開発の初期検討として, 三次 元再構成した頭頸部 CT 画像から頸椎 4 方向撮影に必 要となる基準点を自動検出する自動ポジショニング法 の開発を試みた。

本手法により, CT 画像の模擬人体データから頸椎 4 方向撮影のポジショニングに必要な基準点が正確に 検出され, 基準点からビームセンタの三次元座標を決 定することで，正確なポジショニングが可能となっ た。また, 本研究により, 通常の検査目的で施行され, その後, 医療機関に保管されている大量の CT 検査 デー夕が，一般撮影における撮影技術開発のために必 要な模擬人体データとして利用可能であることが証明 された。
また，本研究のように，既存の CT 画像を用いるこ とで，患者に対する無用な被ばくなしに，撮影法に関 するさまざまな研究が実現可能となることが期待さ れる。

\section{謝 辞}

本研究で用いた CT 画像拉よびデー夕を提供してい ただきました，本学医学部附属病院中央放射線部の羽 手村昌宏様に深く感謝いたします。

本研究の要旨は, 第 74 回日本放射線技術学会総会 学術大会にて発表し, CyPos 賞 (Excellent Student Awards）を受賞しました。

\section{参考文献}

1) Nose H, Shiraishi J. Clinical utility of ultra-low-dose pre-test exposure to avoid unnecessary patient exposure due to positioning errors: a simulation study. Radiol Phys Technol 2017; 10(4): 489-495.

2）塚本信宏。サイバーナイフによる定位放射線治療. RADIOISOTOPES 2018; 67(1): 31-42.

3）久保田佳樹。異業種での映像情報メディア利用〔第 7 回了: 放射線治療のための画像処理. 映像情報メディア学 会誌 2015; 69(7): 580-584.

4) Giger ML, Doi K, MacMahon H. Image feature analysis and computer-aided diagnosis in digital radiography. 3. Automated detection of nodules in peripheral lung fields. Med Phys 1988; 15(2): 158-166.

5）鈴木省吾，市川勝弘，玉木 繁．CTによる ray-summation 画像の画質と臨床的有用性：Digital radiography との比較. 日放技学誌 2017; 73(5): 372-381.

6）小水 満. 放射線画像技術学. 東京：医歯薬出版, 2010 .

7）山下康行, 船間芳憲, 永末 望, 他. 単純 $X$ 線撮影必携. 東京：診断と治療社, 2013. 